\title{
Kako formativno spremljanje pri pouku matematike vpliva na matematično znanje in doživljanje kompetentnosti za učenje matematike?
}

Tanja Rupnik Vec, Mojca Suban

\section{Uvod}

Na Zavodu RS za šolstvo smo v šolskem letu 2018-2019 izvedli raziskavo, v kateri smo na temelju primerjalne analize rezultatov več skupin učencev ugotavljali učinkovitost poučevanja po načelih formativnega spremljanja pri različnih predmetih. $\mathrm{V}$ pričujočem članku prikažemo, analiziramo in interpretiramo del rezultatov omenjene raziskave, ki se nanašajo na pouk matematike. Preverjali smo domnevo, da bodo učenci, ki bodo vključeni v pouk matematike, izvajan po načelih formativnega spremljanja, na avtentičnih preizkusih znanja in veščin dosegli višje rezultate od učencev, ki ne bodo vključeni v pouk, izvajan po načelih formativnega spremljanja. Prav tako smo domnevali, da se bodo učenci v eksperimentalni skupini (poučevani po načelih FS) v primerjavi z učenci v kontrolni skupini (ki niso poučevani po načelih FS) zaznavali kot bolj kompetentni za učenje matematike oz. da bo njihova matematična samopodoba višja.

\section{Teoretični okvir}

\section{Opredelitev formativnega spremljanja}

$\mathrm{V}$ razredih obstajajo številne prakse, utemeljene na raznovrstnih teoretskih izhodiščih, usmerjenih v utemeljevanje strategij za doseganje čim višjih in raznolikih učnih dosežkov učencev. Takšni pristopi so npr. kognitivna akce- 
leracija (Shyer, 1999), samo-uravnavano učenje (npr. Ryan in Deci, 20oo), teorija atribucij (Dweck, 200o). Enega takšnih konceptov predstavlja tudi formativno spremljanje (formative assessment), ki je, tako kot omenjeni in podobni pristopi, usmerjeno v optimiziranje učenja oz. spodbujanje konceptualnega razumevanja učencev. Teorija je še v nastajanju (Black in Wiliam, 2009), predstavlja pa trdni temelj za raznolike razredne prakse ter preverjanje učinkov le-teh. Temeljna ideja koncepta je, da tako učitelj kot učenec, v različnih fazah učnega procesa, prek reševanja najraznovrstnejših miselnih izzivov učenca, pridobivata povratno informacijo o poteku učenja, ki jo izkoristita za nadaljnje korake: učitelj za nadaljnje načrtovanje miselnih dejavnosti za učence, učenec pa za nadgradnjo, izboljšanje svojih dosežkov. Black in William (1998, v Black in Wiliam, 2009: 7) zapišeta: "Praksa v razredu je formativna, če so evidence o dosežkih učencev zbrane, interpretirane in uporabljene tako s strani učiteljev kot učencev in vrstnikov na način, ki vodi do boljših odločitev, kot bi jih sprejeli v odsotnosti teh evidenc." Formativno spremljanje vključuje pet ključnih strategij (prav tam: 4-5): 1. razjasnjevanje in izmenjava namenov učenja in kriterijev uspešnosti, 2. oblikovanje učinkovitih razrednih razprav in drugih učnih dejavnosti, ki omogočajo dokaze o učenčevem razumevanju, 3. zagotavljanje povratne informacije, ki učencu omogoči, da napreduje, 4. spodbujanje učencev kot virov znanja drug za drugega, 5. spodbujanje učencev, da prevzamejo odgovornost za svoje učenje. Podobno te elemente izpostavljajo tudi drugi avtorji (npr. James in sod., 2006). Ključni koncepti so torej povratna informacija, aktivno učenje, sodelovalno učenje ter prevzemanje odgovornosti: "Bistvo vseh teh praks je napraviti učenje eksplicitno in omogočiti oz. spodbuditi učenca, da prevzame kontrolo nad svojim učenjem." (James, prav tam). Keely (2011) opozarja na raznolike funkcije preverjanja oz. vrednotenja znanja. Formativno je preverjanje takrat, kadar je prvenstveno usmerjeno $\mathrm{v}$ spodbujanje učenja. Lahko se dogaja formalno ali neformalno in je integrirano $\mathrm{v}$ različne faze obravnave tematike. Raznolike oblike in tehnike učenca stimulirajo $\mathrm{v}$ razmišljanju o lastnih idejah, učitelj pa $\mathrm{v}$ teh procesih pridobi informacije za nadaljnje načrtovanje učnih izzivov.

\section{Pouk po načelih formativnega spremljanja}

Bistvo pouka po načelih formativnega spremljanja je učiteljevo nenehno spremljanje napredovanja oz. preverjanja doseganja ciljev v skladu s kri-

1 "Preverjanje deluje formativno, če učitelji, učenci in njihovi vrstniki pridobivajo dokaze o napredku pri učencih, ki jih interpretirajo in uporabijo za odločitve o naslednjih korakih v procesu poučevanja, tako, da so te boljše in bolj podprte, kot bi bile odločitve brez teh dokazov." (Wiliam, 2013, str. 136) 
teriji uspešnosti ter prilagajanja poučevanja tem ugotovitvam, kar predpostavlja aktivnost učenca $\mathrm{v}$ vseh fazah učnega procesa (Holcar Brunauer in sod., 2017; Suban in sod., 2018): 1. učenec sodeluje pri načrtovanju namenov učenje in kriterijev uspešnosti, 2. učenec skozi celotni proces učenja zbira raznovrstne dokaze o učenju in jih umešča $\mathrm{v}$ mapo dosežkov, 3. učenec tekom učenja dobi povratno informacijo tako strani učitelja kot s strani sošolcev, kar nadalje usmeri njegovo učenje; učitelj zbranim informacijam prilagodi nadaljnje intervencije, 4. učenec se uči tako, da je v procesu učenja aktiven ter išče odgovore na najraznovrstnejša, predvsem odprta, problemska vprašanja, ki spodbujajo razmišljanje, 5. učenec samo-vrednoti svoje dosežke (in dosežke sošolcev) na temelju dogovorjenih kriterijev, kar mu omogoča načrtovanje nadaljnjih korakov učenja.

Black in Wiliam (2009) poudarjata, da si tako učitelj kot učenec delita odgovornost za proces učenja, učitelj je odgovoren za oblikovanje oz. vzpostavljanje učinkovitega učnega okolja, učenec pa je odgovoren za učenje v tem okolju.

Formativno spremljanje domnevno vpliva na različne vidike funkcioniranja učenk in učencev. Največ raziskav se je - kot je razvidno iz poglavja, ki sledi - osredinilo na vpliv FS na učne dosežke. Ena izmed domnev, ki smo jo preverjali v naši raziskavi je, da ima tovrsten pouk vpliv tudi na učenčevo doživljanje sebe oz. samopodobo (self-concept) in sicer na njen specifičen element, akademsko samopodobo - matematični del (npr. Marsh, 2012). Le-ta, čeprav pri različnih avtorjih spremljana $\mathrm{z}$ različnimi samoocenjevalnimi lestvicami, naj bi v številnih raziskavah korelirala $\mathrm{z}$ različnimi akademskimi dosežki (učni rezultati, aspiracije idr.) (Marsh, prav tam). Dvig matematične samopodobe je torej pomemben vzgojno-izobraževalni cilj. V naši raziskavi smo lestvico, ki preverja matematično samopodobo, sestavili iz štirih postavk in jo poimenovali Lestvica doživljanja matematične kompetentnosti.

\section{Raziskave o spremljanju učinkov formativnega spremljanja}

Black in Wiliam $(1998,2003)$ povzemata ugotovitve več raziskav, v katerih avtorji navajajo pozitivne učinke formativnega spremljanja na učne dosežke učencev, ob tem pa kritično ubesedita raznolike izzive in dileme, ki jih raziskovanje tako kompleksnega pojava prinaša. Ob navajanju študij, ki sklepajo na pozitivne učinke formativnega spremljanja, pa nekateri avtorji (Benett, 2011; Dunn in Mulvenon, 2009) svarijo pred nekritičnim pove- 
ličevanjem tovrstne prakse ter opozarjajo na smiselnost in potrebnost nadaljnjega raziskovanja.

Trumbull in Lash (2013) povzemata rezultate meta-študije, v kateri raziskovalci (Kingstona in Nash, 2012, po Trumbull in Lash, 2013) na temelju analize rezultatov 42 študij ugotavljajo, da so učinki formativnega spremljanja na učne dosežke blagi (velikost učinka, merjen s Cohenovim $\mathrm{d}$, znaša v povprečju o,20 $)^{2}$, vendar večinoma pozitivni, obenem pa precej variabilni. V drugi metaštudiji (Wiliam, Lee, Harrison in Black, 2004, po Trumbull in Lash, prav tam), v kateri so preučevali učinke formativnega spremljanja na dosežke učencev tistih učiteljev, ki so bili pred tem sistematično vključeni v module strokovnega razvoja, pa navaja nekoliko večjo velikost učinka, namreč o,3o.

$\mathrm{V}$ študiji učinkov uporabe tehnik formativnega spremljanja na učne dosežke Pla-Campas in sod. (2016) ugotavljajo, da participacija pri ocenjevanju (samovrednotenje) izboljšuje rezultate učencev. Navajajo tudi rezultate drugih študij, ki dokazujejo vpliv participativnih tehnik ocenjevanja na splošno zaznavanje učenja ter učne rezultate (prav tam).

Posebej malo je znanega o učinkih formativnega spremljanja na dosežke učencev pri matematiki (Van Den Berg in sod., 2017). V meta-analizi, ki sta jo o učinkih formativnega spremljanja na učne dosežke opravila Kingston in Nash (2011), je mogoče zaslediti le pet študij, ki se nanašajo na matematično izobraževanje. Te študije navajajo velikost učinka na učne dosežke med o,14 do o,20 (n=19), kar je po Cohenu (1988, po Van Den Berg in sod, 2017) majhen učinek (prav tam).

Med novejšimi študijami iz evropskega prostora omenimo dve: prva je nizozemska in je bila izvedena $v 4$. in 5. razredu s 34 učitelji iz 15-ih šol (Van Den Berg in sod., 2017), druga pa je nemška, izvedena v 9. razredu s 26 učitelji iz 18 šol (Rakoczy in sod., 2019). Nobena od omenjenih dveh študij ni dala enoznačnega odgovora o učinkih formativnega spremljanja na dosežke učencev. V prvi študiji so zaznali blage učinke stopnje implementacije formativnega spremljanja na dosežke učencev v 5. razredu, v 4. pa ne. $\mathrm{V}$ drugi študiji niso zaznali statistično pomembnega učinka na dosežke učencev, izmerili pa so povečanje samoučinkovitosti. V obeh študijah avtorji iz-

2 Velikost učinka oz. Cohenov d je mera, ki pomaga pri odločitvi o tem, ali je razlika, ki je statistično pomembna, pomembna tudi praktično (Cankar in Bajec, 2003, Hattie, 2009). Vrednosti d okoli o,2 predstavljajo majhen učinek (92,3 \% enakih rezultatov v obeh skupinah), vrednosti okoli o,8 pa velik učinek (52,6 \% enakih rezultatov v obeh skupinah) (Kirk, 1996, po Cankar in Bajec, prav tam) 
postavljajo številne omejitve svojih raziskav in pozivajo $\mathrm{k}$ nadaljnjim raziskavam na tem področju.

\section{Cilji raziskave in raziskovalna vprašanja}

Namen raziskave je bil ugotoviti učinke formativnega spremljanja na dosežke, motivacijo za učenje, kakovost odnosov pri matematiki. S tem v zvezi so nas zanimale razlike med učenci, ki so poučevani po načelih formativnega spremljanja od učencev, ki niso bili poučevani po teh načelih, na področjih:

- učnih dosežkov oz. znanja matematike,

- doživljanja kompetentnosti za učenje matematike

\section{Hipoteze}

Hipoteza 1: Učenci, ki so vključeni v proces učenja in poučevanja po načelih formativnega spremljanja bodo dosegli višjo kakovost matematičnega znanja in prečnih veščin kot učenci, ki niso vključeni $\mathrm{v}$ tak proces.

Hipoteza 2: Učenci, poučevani po načelih formativnega spremljanja se bodo za učenje matematike doživljali bolj kompetentno kot učenci, ki niso poučevani po načelih formativnega spremljanja.

\section{Metodologija}

\section{Vzorec}

Raziskava je potekala $\mathrm{v}$ osnovni šoli pri pouku matematike $\mathrm{v}$ 7. razredu in $\mathrm{v}$ srednji šoli v 2. letniku. V eksperimentalno skupino (učenci, ki so bili poučevani po načelih formativnega spremljanja) je bilo vključenih 5 osnovnih šol $(\mathrm{N}=66)$ in 2 srednji šoli $(\mathrm{N}=60)$. $\mathrm{V}$ kontrolno skupino (učenci, ki niso bili poučevani po načelih formativnega spremljanja) pa so bile vključene 4 osnovne šole $(\mathrm{N}=85)$ in 2 srednji šoli (gimnazija in srednja strokovna šola; $N=43$ ). Analize so bile narejene na različnem številu učencev v odvisnosti od zahtev posameznega statističnega izračuna (npr. t-testi za odvisne vzorce so izračunani zgolj za učence oz. dijake, ki so sodelovali v obeh merjenjih). 


\section{Postopek}

Raziskava je potekala $v$ šol. letu 2018/2019 in sicer od začetka oktobra 2018 do junija 2019, v skladu z eksperimentalnim načrtom, dogovor za sodelovanje $\mathrm{z}$ učitelji pa je potekal že mesec pred tem. K sodelovanju smo povabili učiteljice in učitelje matematike, ki z Zavodom RS za šolstvo intenzivno sodelujejo v razvojni nalogi Formativno spremljanje, ter učitelje in učiteljice, ki v razvojni nalogi ne sodelujejo in domnevno pouka ne izvajajo sistematično po načelih formativnega spremljanja. Preizkus znanja in veščin, vprašalnike in intervju $\mathrm{z}$ učenci $\mathrm{v}$ fokusnih skupinah (rezultati niso predmet tega članka) smo izvajali dvakrat, kot pred-test (oktober, november 2018) ter kot post-test (april do junij 2019). Raziskali smo razlike med dosežki učencev in dijakov v kontrolni in eksperimentalni skupini ter med dosežki učencev in dijakov znotraj posamezne skupine (eksperimentalna, kontrolna) na pred in post-testu.

\section{Opis instrumentarija}

Vrednotenje znanja in veščin je potekalo na temelju preverjanja vsebinskega znanja matematike ter veščin podajanja povratne informacije in samovrednotenja $\mathrm{z}$ avtentičnimi nalogami. Pri reševanju nalog se je izmenjalo več faz samostojnega reševanja in reševanja $\mathrm{v}$ paru s sošolcem.

Vrednotenje doživljanja kompetentnosti za učenje matematike smo ugotavljali s 4-itemskim vprašalnikom $\mathrm{z}$ visoko zanesljivostjo (Crombach alpha $=0,91$ ), učenci so označili stopnjo strinjanja s posamezno postavko na 5-stopenjski lestvici ( 1 - sploh se ne strinjam, 2 - se precej ne strinjam, 3 - se niti ne strinjam niti se strinjam, 4 - se precej strinjam, 5 - popolnoma se strinjam). Postavke vprašalnika: "Pri matematiki sem se sposoben veliko naučiti.", "Pri učenju matematike vem, kdaj sem uspešen.", Zadovoljen sem s svojimi rezultati pri matematiki.", "Kadar se pri matematiki potrudim, sem uspešen.”

\section{Rezultati}

Hipoteza 1: Osnovna šola

Iz rezultatov (tabela 36 ) je razvidno, da so učenci v eksperimentalni skupini že v izhodišču dosegli na testu preverjanja matematičnih znanj in veščin statistično pomembno višje rezultate od učencev kontrolne skupine $\left(_{\mathrm{ES}}=68,94,_{\mathrm{KS}}=61,42, \mathrm{t}=3,05, \mathrm{p}=0,003\right)$. Ta razlika se je od prvega do drugega merjenja zmanjšala. Na postavkah, vezanih na znanje, so na predtestu 
učenci v eksperimentalni skupini v povprečju dosegli 79,97 \% točk, učenci v kontrolni skupini pa 75,69 \% točk, kar je primerljiv rezultat $(\mathrm{t}=1,213$, $\mathrm{p}=0,227)$ za razliko od postavk, vezanih na veščine, kjer so učenci v eksperimentalni skupini dosegli v povprečju $62,32 \%$ točk, kar je statistično boljši rezultat, kot so ga dosegli učenci v kontrolni skupini $(52,86 \%$; $t=3,646$, $\mathrm{p}=\mathrm{o}, \mathrm{ooo})$.

Tabela 36: Rezultati osnovnošolcev v eksperimentalni in v kontrolni skupini na prvem merjenju (pred-test) in drugem merjenju znanja in veščin

\begin{tabular}{llllllllll} 
& & \multicolumn{3}{c}{ Eksperimentalna skupina } & \multicolumn{3}{c}{ Kontrolna skupina } & \multicolumn{2}{c}{ t-test } \\
\cline { 2 - 9 } & $(\%)$ & $\mathrm{N}$ & $\mathrm{SD}$ & $(\%)$ & $\mathrm{N}$ & $\mathrm{SD}$ & $\mathrm{t}$ & $\mathrm{p}$ \\
\hline \multirow{2}{*}{$\begin{array}{l}\text { Pred- } \\
\text {-test }\end{array}$} & Znanje & 79,97 & 66 & 19,22 & 75,69 & 85 & 24,16 & 1,21 & 0,227 \\
\cline { 2 - 9 } & Veščine & 62,32 & 66 & 16,72 & 52,86 & 85 & 15,08 & 3,65 & 0,000 \\
\cline { 2 - 9 } & Skupaj & 68,94 & 66 & 14,71 & 61,42 & 85 & 15,24 & 3,05 & 0,003 \\
\multirow{2}{*}{$\begin{array}{l}\text { Post- } \\
\text {-test }\end{array}$} & Znanje & 77,27 & 66 & 17,80 & 81,96 & 85 & 19,77 & $-1,51$ & 0,133 \\
\cline { 2 - 9 } & Veščine & 63,13 & 66 & 14,52 & 59,61 & 85 & 17,04 & 1,34 & 0,181 \\
\cline { 2 - 9 } & Skupaj & 68,43 & 66 & 13,58 & 67,99 & 85 & 15,62 & 0,18 & 0,855
\end{tabular}

$\mathrm{Na}$ post-testu so učenci $\mathrm{v}$ eksperimentalni skupini dosegli podoben skupni rezultat kot učenci v kontrolni skupini $\left(_{\mathrm{ES}}=68,43{ }_{\mathrm{KS}}=67,99\right.$, $\mathrm{t}=\mathrm{o}, 18, \mathrm{p}=\mathrm{o}, 855)$. Podobno lahko ugotovimo tudi za rezultat na postavkah, vezanih na znanje $(\mathrm{t}=-1,51, \mathrm{p}=0,13)$, in za rezultat na postavkah, vezanih na veščine $(t=1,34, p=0,18)$. Osnovnošolci v eksperimentalni skupini so visoke dosežke iz prvega merjenja ohranili tudi pri drugem merjenju. Učenci v kontrolni skupini so od prvega do drugega merjenja napredovali. Statistično pomembno boljši so bili tako v skupnem dosežku $(\mathrm{N}=85, \mathrm{t}=-3,7 \mathrm{O}$, $\mathrm{p}=\mathrm{o}, \mathrm{Ooo})$, kot na postavkah, vezanih na veščine $(\mathrm{N}=85, \mathrm{t}=-3,57, \mathrm{p}=0,001)$, pa tudi na postavkah, vezanih na matematično konceptualno znanje $(\mathrm{N}=85$, $\mathrm{t}=-2,18, \mathrm{p}=\mathrm{o}, \mathrm{O} 32)$.

\section{Hipoteza 1: Srednja šola}

Avtentična naloga, ki so jo dijaki reševali na pred-testu, je bila ovrednotena z 28 točkami. Dijaki v eksperimentalni skupini so dosegli povprečno 15,28 točk (54,57\%), dijaki v kontrolni skupini pa 15,77 točk $(56,32 \%)$, kar je primerljiv rezultat. Enako velja tudi za delne rezultate, ki kažejo, da se skupini na pred-testu nista razlikovali glede na matematično znanje in preverjane veščine (tabela 37). Avtentična naloga, ki so jo dijaki reševali na post-testu, je bila ovrednotena s 25 točkami. Dijaki v eksperimentalni skupini so skupno dosegli v povprečju 13,08 oz. 52,33\% točk, kar je statistično 
pomembno višji rezultat $(\mathrm{t}=2,46, \mathrm{p}=0,016)$ od rezultata dijakov v kontrolni skupini (11,28 oz. 45,12 \%). Razlika med obema skupinama je pomembna na postavki »veščine« $(\mathrm{t}=2,56, \mathrm{p}=0,012)$, ne pa na postavki »znanje» $(\mathrm{t}$ $=1,74, \mathrm{p}=0,085)$.

Tabela 37: Rezultati dijakov v eksperimentalni in dijakov v kontrolni skupini na prvem in drugem merjenju znanja in veščin

\begin{tabular}{|c|c|c|c|c|c|c|c|c|c|}
\hline & \multicolumn{3}{|c|}{ Eksperimentalna skupina } & \multicolumn{3}{|c|}{ Kontrolna skupina } & \multicolumn{2}{|c|}{ t-test } \\
\hline & & $(\%)$ & $\mathrm{N}$ & $\mathrm{SD}$ & $(\%)$ & $\mathrm{N}$ & SD & $\mathrm{t}$ & $\mathrm{p}$ \\
\hline \multirow{3}{*}{$\begin{array}{l}\text { Pred- } \\
\text {-test }\end{array}$} & Znanje & 58,19 & 60 & 21,725 & 57,75 & 43 & 29,175 & 0,08 & 0,933 \\
\hline & Veščine & 51,88 & 60 & 14,478 & 55,23 & 43 & 19,855 & $-0,94$ & 0,349 \\
\hline & Skupaj & 54,58 & 60 & 13,605 & 56,31 & 43 & 18,175 & $-0,53$ & 0,600 \\
\hline \multirow{3}{*}{$\begin{array}{l}\text { Post- } \\
\text {-test }\end{array}$} & Znanje & 46,54 & 60 & 18,161 & 40,25 & 43 & 17,988 & 1,74 & 0,085 \\
\hline & Veščine & 58,61 & 60 & 16,664 & 50,39 & 43 & 15,209 & $2,56^{*}$ & 0,012 \\
\hline & Skupaj & 52,33 & 60 & 15,044 & 45,12 & 43 & 14,218 & $2,46^{*}$ & 0,016 \\
\hline
\end{tabular}

Dijaki v eksperimentalni skupini so od prvega do drugega merjenja (tabela 38) statistično pomembno napredovali na postavkah, vezanih na veščino $(\mathrm{t}=-2,898, \mathrm{p}=0,005)$, statistično pomembno pa nazadovali pri postavkah, vezanih na znanje $(t=3,770, p=0,000)$, ki pa sicer ni bilo znanje iz istih vsebin kot pri prvem merjenju. Skupno so ohranili raven dosežka iz prvega merjenja.

Tabela 38: Rezultati dijakov eksperimentalne in kontrolne skupine na prvem merjenju (pred-test) in drugem merjenju znanja in veščin

\begin{tabular}{|c|c|c|c|c|c|c|c|c|c|}
\hline & \multicolumn{3}{|c|}{ Pred-test } & \multicolumn{3}{|c|}{ Post-test } & \multicolumn{2}{|c|}{$\begin{array}{c}\text { t-test } \\
\text { (odv. vzorci) }\end{array}$} \\
\hline & & $(\%)$ & $\mathrm{N}$ & SD & $(\%)$ & $\mathrm{N}$ & SD & $\mathrm{t}$ & $\mathrm{p}$ \\
\hline \multirow{3}{*}{$\begin{array}{l}\text { Eksperi- } \\
\text { mentalna } \\
\text { skupina }\end{array}$} & Znanje & 58,19 & 60 & 21,725 & 46,54 & 60 & 18,161 & 3,770 & 0,000 \\
\hline & Veščine & 51,88 & 60 & 14,478 & 58,61 & 60 & 16,664 & $-2,898$ & 0,005 \\
\hline & Skupaj & 54,58 & 60 & 13,605 & 52,33 & 60 & 15,044 & 1,053 & 0,297 \\
\hline \multirow{3}{*}{$\begin{array}{l}\text { Kontrol- } \\
\text { na sku- } \\
\text { pina }\end{array}$} & Znanje & 57,75 & 43 & 29,175 & 40,25 & 43 & 17,988 & 4,739 & 0,000 \\
\hline & Veščine & 55,23 & 43 & 19,855 & 50,39 & 43 & 15,209 & 1,581 & 0,121 \\
\hline & Skupaj & 56,31 & 43 & 18,175 & 45,12 & 43 & 14,218 & 4,718 & 0,000 \\
\hline
\end{tabular}

Dijaki v kontrolni skupini so od prvega do drugega merjenja statistično pomembno poslabšali svoje rezultate (tabela 38 ). Statistično slabši so rezultati na postavkah, vezanih na konceptualno matematično znanje $(\mathrm{t}=4,739, \mathrm{p}=0,000)$, in v skupnem dosežku $(\mathrm{t}=4,718, \mathrm{p}=0,000)$, ne pa na postavkah, vezanih na preverjane veščine $(t=1,581, p=0,121)$. 
Hipoteza 2: Osnovna šola

Učenci v eksperimentalni skupini so na Lestvici doživljanja kompetentnosti za učenje matematike $\mathrm{v}$ začetku šolskega leta dosegli $\mathrm{v}$ povprečju 16,07 točk, pri merjenju ob koncu šolskega leta pa so dosegli v povprečju 15,15 točk (tabela 39). Razlika je statistično pomembna $(\mathrm{t}=2,36, \mathrm{df}=60$, $\mathrm{p}=\mathrm{o}, \mathrm{o2}$ ), doživljanje kompetentnosti za učenje matematike se je tekom leta $\mathrm{v}$ tej skupini znižalo. V kontrolni skupini je trend podoben, vendar razlika med prvim in drugim merjenjem ni pomembna $(t=1,76, d f=66, p=0,08)$.

\section{Tabela 39: Povprečni dosežki osnovnošolcev v eksperimentalni in v kontrolni skupini na pred in post-testu ter pripadajoči t-testi razlik med obema merjenja znotraj posamezne skupine}

\begin{tabular}{llllll} 
& & $\mathrm{N}$ & & $\mathrm{SD}$ & $\mathrm{t}(\mathrm{p})$ \\
\multirow{2}{*}{ ES } & Dož_komp_pred & 61 & 16,07 & 2,88 & $2,36(0,022)^{*}$ \\
\cline { 2 - 6 } & Dož_komp_po & 61 & 15,15 & 3,35 & \\
\multirow{2}{*}{ KS } & Dož_komp_pred & 67 & 15,97 & 3,48 & $1,76(0,08)$ \\
\cline { 2 - 6 } & Dož_komp_post & 67 & 15,33 & 3,39 &
\end{tabular}

Legenda: ES - eksperimentalna skupina, KS - kontrolna skupina; pred-pred-test, post posttest

Medsebojna primerjava rezultatov eksperimentalne in kontrolne skupine osnovnošolcev je pokazala, da razlike med njima niso bile statistično pomembne niti pri prvem $(\mathrm{t}=-0,40, \mathrm{df}=184, \mathrm{p}=0,69)$ niti pri drugem merjenju $(t=-0,301, d f=129, p=0,76)$.

Hipoteza 2: Srednja šola

Srednješolci $\mathrm{v}$ eksperimentalni skupini $(\mathrm{N}=45)$ so na Lestvici doživljanja kompetentnosti za učenje matematike pri prvem merjenju dosegli v povprečju 16,15 točk $(\mathrm{SD}=2,41)$, pri drugem merjenju pa so v povprečju dosegli 15,37 točk $(S D=2,43)$. Razlika statistično ni pomembna, torej se doživljanje kompetentnosti za učenje matematike pri srednješolcih $\mathrm{v}$ eksperimentalni skupini skozi leto ni spremenilo. V kontrolni skupini je situacija enaka, razlika $\mathrm{v}$ povprečnem dosežku dijakov na tej lestvici na začetku šolskega leta ter ob koncu šolskega leta ni bila pomembna $(t=1,76, d f=43, p=0,8)$ 
Tabela 40: Povprečni dosežki srednješolcev pri prvem in drugem merjenju na Lestvici doživljanja kompetentnosti za učenje matematike ter pripadajoča t-testa

\begin{tabular}{lccccc} 
& ES/KS & N & & SD & t (p) \\
Dož_komp_pred & ES & 51 & 16,25 & 2,48 & $4,39(0,000)$ \\
\hline & KS & 61 & 13,93 & 3,02 & \\
\hline Dož_komp_post & ES & 46 & 15,67 & 2,44 & $4,58(0,000)$ \\
\hline & KS & 44 & 12,84 & 3,37 &
\end{tabular}

Legenda: pred - pred-test, post = post-test; ES - eksperimentalna skupina, KS = kontrolna skupina, VSU - veščine samouravnavanja, Dož_komp - doživljanje kompetentnosti.

Obstajala pa je statistično pomembna razlika v povprečnih dosežkih na lestvici doživljanja kompetentnosti za učenje matematike med skupino dijakov v eksperimentalni skupini in skupino dijakov v kontrolni skupini, pri obeh merjenjih (tabela 40), v korist dijakov v eksperimentalni skupini, ki so se v povprečju doživljali bolj kompetentno za učenje matematike kot njihovi vrstniki v kontrolni skupini.

\section{Razprava}

$\mathrm{V}$ raziskavi smo preverjali dve hipotezi, ki se nanašata na razlike v znanju in v doživljanju učencev, ki so poučevani po načelih formativnega spremljanja $\mathrm{v}$ primerjavi z učenci, ki niso poučevani po teh načelih. Domnevali smo, da pouk, ki poteka po načelih formativnega spremljanja, bolj pozitivno vpliva na nekatere vidike doživljanja pouka ter na znanje in (samooceno) veščin učencev, v primerjavi s poukom, ki ne poteka po teh načelih. Rezultati raziskav drugih raziskovalcev namreč pritrjujejo nekaterim našim domnevam (npr. Mehmood in sod. 2012; Peat in sod., 2005; Rakoczy in sod., 2019). Raziskavo smo zasnovali kot eksperiment, ki je vključeval eksperimentalno in kontrolno skupino ter merjenje različnih spremenljivk pred intervencijo in po intervenciji. V eksperimentalno skupino smo zajeli učence učiteljev, ki od leta 2018 sodelujejo v razvojni nalogi Formativno spremljanje Zavoda RS za šolstvo. Raziskavo smo izvajali v času oktobra in novembra 2018 za izvedbo pred-testa ter v maju in juniju 2019 za izvedbo post-testa. Med izvedbo pred-testa in post-testa je v eksperimentalni skupini teklo delo po načelih formativnega spremljanja. Obseg, trajanj in poglobljenost pouka po načelih formativnega spremljanja učiteljev smo spremljali neformalno, na srečanjih v okviru razvojne naloge, kjer so učitelji preverjali svoje rešitve v dialogu s kolegi in bili deležni spodbud za tovrsten pouk. Prav tako nismo 
posebej spremljali poučevalnih metod v kontrolni skupini, zato ni mogoče izključiti možnosti, da so občasno nekateri učitelji v kontrolni skupini uporabili katerega od vidikov formativnega spremljanja, vendar ne sistematično in načrtno v obdobju med pred-testom in post-testu. Prva hipoteza se je nanašala na učinke formativnega spremljanja na kakovost znanja in veščin, preverjanih $\mathrm{z}$ avtentično nalogo.

Rezultati, ki so jih dosegli osnovnošolci v eksperimentalni in v kontrolni skupini pri reševanju avtentične naloge pri prvem merjenju (pred-test) pokažejo, da so učenci eksperimentalne skupine na celotnem testu dosegli pomembno višji rezultat od učencev kontrolne skupine, $\mathrm{k}$ čemer je prispeval predvsem dosežek na vprašanjih, ki so preverjala veščine (razlika med skupinama je 9,46 odstotnih točk). Konceptualno matematično znanje pa sta obe skupini izkazali v enaki meri. $Z$ izborom $v$ eksperiment vključenih šol smo zagotovili, da $\mathrm{v}$ eksperimentalnih razredih poučujejo učitelji matematike, ki sodelujejo $\mathrm{v}$ razvojnih nalogah ZRSŠ s področja uvajanja in razvijanja načel formativnega spremljanja že več let, kar pomeni, da so bili učenci v eksperimentalni skupini deležni poučevanja po načelih formativnega spremljanja že v letih pred začetkom eksperimenta. Prav začetna razlika v dosežku učencev, ki so bili že dlje časa poučevani po načelih formativnega spremljanja ter učenci, ki niso bili poučevani po teh načelih, na avtentični nalogi, je indic, ki nakazuje nekoliko večjo učinkovitost poučevanja po načelih formativnega spremljanja $\mathrm{v}$ primerjavi s poukom, ki ni izvajan po teh načelih in potrjuje našo hipotezo. Pri tem je smiselno izpostaviti, da se ta učinek izkazuje predvsem na usvajanje veščin, kjer so učenci v eksperimentalni skupini znatno presegli učence kontrolne skupine, manjši učinek pa je $\mathrm{v}$ našem primeru imelo formativno spremljanje na konceptualno matematično znanje. Razlika v izkazovanju veščin med učenci v obeh skupinah je torej pričakovana, saj je eno temeljnih načel formativnega spremljanja vključevanje učencev $\mathrm{v}$ dejavnosti izmenjave povratne informacije ter samorefleksije, torej veščin, ki sta bili v avtentični nalogi, ki so jo učenci reševali v eksperimentu, močno izpostavljeni. Učenci v kontrolni skupini s temi aktivnostmi predhodno niso imeli izkušenj, zato so posledično, že pri prvem merjenju, dosegli nižji rezultat. Kljub temu, da so tudi na post-testu učenci v eksperimentalni skupini dosegli nekoliko boljši rezultat od učencev kontrolne skupine, pa napredek eksperimentalne skupine v konceptualnem znanju tekom šolskega leta, $v$ katerem je trajala intervencija, ni bil zaznan. Učenci v eksperimentalni skupini so ohranili raven (visokih) dosežkov v obeh kategorijah (znanje in veščine). Zaznan pa je bil pomemben 
napredek kontrolne skupine na obeh postavkah, tistih, vezanih na vsebino in tistih, vezanih na proces (veščino). To bi morda lahko delno pojasnili s tem, da so bili tudi učenci v kontrolni skupini potencialno deležni spodbud, značilnih za poučevanje po načelih formativnega spremljanja. Čeprav je bil izbor tako eksperimentalnih kot kontrolnih učiteljev skrben, ni mogoče v celoti izključiti možnosti, da so občasno nekateri učitelji v kontrolni skupini, zavedajoč se, da sodelujejo v eksperimentu, uporabili katero od načel formativnega spremljanja ali pa kakšno drugo strategijo, ki je prispevala k napredku njihovih učencev v šolskem letu, v katerem je bil izvajan eksperiment. Učitelji, ki so poučevali v kontrolni skupini so se lahko udeležili izobraževanj s to tematiko, ki jo na ZRSŠ razvijamo že vrsto let, v zadnjih štirih letih pa usklajeno z vsemi učitelji na študijskih srečanjih.

V srednji šoli sta bili na pred-testu eksperimentalna in kontrolna skupina dijakov po rezultatih zelo izenačeni, kar kaže na to, da sta bili najverjetneje po predhodnih učnih izkušnjah približno enaki. Na post-testu so dijaki eksperimentalne skupine pokazali napredek na postavkah, vezanih na veščine, kjer so dosegli za 8,22 odstotnih točk višji rezultat v primerjavi z učenci kontrolne skupine. Razlike znotraj posamezne skupine, ki so se zgodile tekom leta, v katerem je (v eksperimentalni skupini) potekala intervencija so vse statistično pomembe. V kategoriji znanje, so tako dijaki v eksperimentalni kot dijaki v kontrolni skupini nazadovali. Ta rezultat lahko nakazuje razliko v dojemanju vsebine, ki je bila predmet avtentične naloge, lahko pa nakazuje tudi, da formativno spremljanje na konceptualno znanje matematike dejansko nima tako močnega učinka, kar kaže tudi rezultat pri osnovnošolcih. Druga pomembna ugotovitev pa se nanaša na dosežek, vezan na veščine. Dijaki v eksperimentalni skupini so v veščini pomembno napredovali, dijaki v kontrolni skupini pa dosežku, ki se nanaša na veščino, ne kažejo izboljšanja. Tudi ta rezultat pritrjuje naši hipotezi, ki se nanaša na prednost pouka po načelih formativnega spremljanja $\mathrm{v}$ primerjavi s poukom, ki ne poteka po teh načelih. Na temelju zgornjih ugotovitev sklepamo, da pouk po načelih formativnega spremljanja dejansko predstavlja prednost za učenje (preučevanih) veščin, za sklep o prednosti formativnega spremljanja pred drugimi paradigmami poučevanja za izgradnjo konceptualnega znanja, pa v našem eksperimentu dokazi niso prepričljivi.

Druga hipoteza se je nanašala na doživljanje kompetentnosti za učenje matematike pri osnovnošolcih oz. pri srednješolcih. Predpostavili smo, da bodo intervencije učiteljev, značilne za formativno spremljanje prispevale k izgradnji prepričanj, da je matematika zanje obvladljiva, in bodo posle- 
dično, na Lestvici doživljanja kompetentnosti, pri drugem merjenju dosegli višji rezultat $\mathrm{v}$ primerjavi $\mathrm{z}$ učenci $\mathrm{v}$ kontrolni skupini, ter da bodo učenci $\mathrm{v}$ eksperimentalni skupini $\mathrm{v}$ tem doživljanju tekom leta pomembno napredovali, medtem ko bo doživljanje kompetentnosti pri učencih/dijakih v kontrolni skupini tekom leta ostalo na isti ravni. Eno izmed načel formativnega spremljanja je namreč izpostavljanje pomena konstruktivne povratne informacije učencu na učni dosežek (izkazan na najrazličnejše načine) ter spodbuda, da svoj dosežek nadgradi oz., da doseže višjo raven (Black in Wiliam, 2009, 2011). Možnost nadgrajevanja lastnega znanja ter tovrstno spremljanje napredka pa učencu omogoči prevzemanje nadzora nad učenjem s tem pa močnejše doživljanje kompetentnosti (doživljanje "zmorem") ter motiviranosti (Dweck, 200o).

Nobena od domnev, vezanih na doživljanje kompetentnosti za učenje matematike, $\mathrm{v}$ eksperimentu ni bila potrjena. $\mathrm{V}$ osnovnošolski skupini učencev je doživljanje kompetentnosti tekom leta upadlo, za razliko od doživljanja učencev v kontrolni skupini, ki so pri obeh merjenjih izkazali isti rezultat. Podoben rezultat smo našli v skupini srednješolcev. Povratna informacija in kompleksen, drugačen pouk, temelječ na reševanju problemov in sodelovalnem delu, torej $\mathrm{v}$ našem eksperimentu ni prispeval k dvigu doživljanja kompetentnosti za učenje matematike. Izmerili pa smo razliko med obema skupinama pri prvem merjenju, ki se je tekom leta ohranila: doživljanje kompetentnosti za učenje matematike pri dijakih v eksperimentalni skupini pri prvem merjenju pomembno močnejše od povprečnega doživljanja dijakov v kontrolni skupini. Ta razlika morebiti kaže na pozitivni učinek formativnega spremljanja, saj smo merjenje opravili v drugem letniku, ko so dijaki v eksperimentalni skupini že imeli za seboj leto pouka po načelih formativnega spremljanja. Tekom šolskega leta se je doživljanje kompetentnosti v obeh skupinah sicer pomembno zmanjšalo, podobno kot pri osnovnošolcih, razlika med skupinama pa se je ohranila. Upad doživljanja kompetentnosti morda lahko pojasnimo kot posledico soočenja $\mathrm{z}$ realnostjo zahtev pouka ter uspehov in neuspehov, ki jih učenec med letom pri učenju doživlja in ki prinesejo morebitni upad začetnega optimizma in verjetje v uspeh ter doživljanje "zmorem «. Začetna razlika med dijaki kontrolne in eksperimentalne skupine nakazuje morebitno prednost pouka po načelih formativnega spremljanja na dimenziji doživljanja kompetentnosti dijakinj in dijakov. Zaključek ni zanesljiv, saj ne vemo, kako točno je potekal pouk oz. v kolikšni meri so učitelji, ki so se opredelili kot »formativci«, dejansko vodili pouk v skladu z načeli formativnega spremljanja. Ena iz- 
med domnev, ki izhaja iz kontinuiranega stika z njimi je, da se v svojih začetnih poskusih poučevanja po načelih FS osredinjajo zgolj na eno izmed načel, namreč načelo aktivnega zbiranja dokazov, ne pa toliko na načeli, ključni za spodbudo učencu k napredovanju: konstruktivna povratna informacija ter samoevalvacija. Sicer pa avtorji pouka po načelih formativnega spremljanja (Black in Wiliam, 2009) opozarjajo, da učinki poučevanja po načelih formativnega spremljanja niso vidni takoj, torej po intervencijah, ki trajajo krajši čas, nekaj mesecev, med katere uvrščamo tudi naš eksperiment. Nekatere metaštudije (Trumbul in Lash, 2013) pa navajajo tudi, da so učinki (merjeni so bili predvsem učinki na znanje) blagi, so pa nekoliko višji pri učiteljih z daljšim stažem poučevanja. Naš raziskovalni optimizem, da bo povratna informacija in dosledno izvajana spodbuda in možnost učencev, da svoje izdelke izboljšujejo, vplivala na njihovo percepcijo "zmorem« kratkoročno, ni bil povsem upravičen. Upoštevaje te ugotovitve bi bilo smiselno pri bodočem načrtovanju tovrstnih eksperimentov upoštevati dvoje: učitelje v eksperimentalni skupini bolj sistematično usmerjati pri načrtovanju učnih strategij in s tem pridobiti vpogled v intenzivnost in kakovost formativnih intervencij, učinke na učence pa meriti po nekoliko dalj časa trajajoči intervenciji (npr. po drugem letu udeležbe učencev v tako vodenem procesu učenja).

\section{Omejitve raziskave in odprta vprašanja}

Pričujoča raziskava se dogaja v avtentični pedagoški situaciji, kar samo po sebi prinaša določene omejitve, ki jih je smiselno upoštevati pri interpretaciji rezultatov. Prvo omejitev raziskave predstavlja izbira in velikost vzorca učiteljev ter možnost vpogleda v njihovo vsakodnevno prakso. V eksperimentalno skupino smo uvrstili učiteljice in učitelje $z$ daljšim stažem in vidnejšim prispevkom v razvojni nalogi Formativno spremljanje Zavoda RS za šolstvo, v kontrolno skupino pa smo povabili učitelje, ki sicer tudi obiskujejo študijske skupine, ki delno omogočajo vpogled v njihovo delo, obenem pa niso člani razvojne skupine in - domnevno - sistematično ne izvajajo tega pristopa. Raziskava torej bolj kot na dejanskem vpogledu v prakso učiteljev temelji na dveh predpostavkah: da so "pravi formativci« učitelji z daljšim intenzivnim usposabljanjem na tem področju (dolgotrajnost procesa usposabljanja kot dejavnik učinkovitosti poučevanja omenjata tudi Black in William, 2003) in da je preobrazba temeljnih prepričanj učiteljev v novo paradigmo dolgotrajen proces refleksije oz. izgradnje (ali nadgradnje) subjektivne teorije (Korthagen, 1999). Trajnejše, aktivno in vidno udejstvo- 
vanje v razvojni nalogi Formativno sklepanje po našem mnenju dopušča sklep, da so za formativno spremljanje ti učitelji bolje opremljeni kot učitelji, ki imajo s konceptom zgolj površen kontakt ali pa ga sploh nimajo. Ob vsem zavedanju, da intervencij, ki so v skladu $\mathrm{z}$ načeli formativnega spremljanja pri kontrolni skupini učiteljev ne moremo v celoti izključiti, kar predstavlja okoliščino, ki terja previdnost pri sklepanju.

Drugo omejitev predstavlja zahtevnost priprave avtentične naloge, $\mathrm{s}$ katero smo želeli meriti učinek poučevanja po načelih formativnega spremljanja na kakovost znanja in veščin pri matematiki. Naloge za pred-test in post-test so bile strukturirane, odprte, avtentične naloge, $\mathrm{v}$ katerih smo merili vsebinsko znanje matematike in procesno znanje oz. veščine. Matematične vsebine, ki so bile vključene v pred-test in post-test, niso bile identične in izkazalo se je, da naloge pred-testa in post-testa za učence niso bile identične po težavnosti, pač pa se je vsebina post-testa izkazala za zahtevnejšo od vsebine pred-testa, ne glede na to, da so bile naloge taksonomsko enako sestavljene. To zavedanje otežuje primerjavo dosežkov na pred- in post-testu, s tem pa izpeljavo veljavnih sklepov za kategorijo »znanje«. Da lahko stopnja težavnosti in kompleksnosti naloge vpliva na dosežke učencev, je ena od ugotovitev študije nizozemskih raziskovalcev (Van Den Berg in sod., 2017), ki smo jo omenili v 1.3. Ugotovili so, da je bil večji napredek zaznan pri učencih $v$ 5. razredu, kjer so imeli težjo in bolj kompleksno nalogo $\mathrm{v}$ primerjavi $\mathrm{z}$ učenci $\mathrm{v}$ 4. razredu. $\mathrm{V}$ primeru ponovitve naše raziskave bi posebno pozornost namenili težavnosti naloge, zato bi kazalo naloge pred uporabo pilotirati in empirično opredeliti njihovo težavnost.

Postavke, ki so bile vezane na veščine, pa so bile enake $\mathrm{v}$ pred-testu in post-testu, zato zaključevanje v kategoriji »veščine«ni sporno.

V raziskavi se odpira vrsta vprašanj, tako metodoloških, kot vsebinskih. Nekatera vprašanja so vezana na zgoraj opisane omejitve, npr. kaj bi pokazali rezultati, če bi bile intervencije učiteljev bolj nadzorovane, kolikšen vpliv na nekatere dimenzije doživljanja učencev ima učiteljev odnos oz. komunikacijski stil? Odpira se tudi vprašanje, koliko časa je potrebno, da se intervencije učiteljev odrazijo na dosežkih učencev. Druga vprašanja pa so vezana na samo konceptualizacijo formativnega spremljanja, npr. kakšen vpliv oz. učinek ima na znanje in doživljanje učencev posamezen element formativnega spremljanja (npr. so-načrtovanje kriterijev uspešnosti, učiteljeva povratna informacija, vrstniška povratna informacija, samoevalvacija ...) itd.? 


\section{Sklep}

Čeprav rezultati pričujoče študije niso enoznačni in vse naše hipoteze niso potrjene, pa lahko $\mathrm{z}$ neko verjetnostjo sklepamo na nekatere prednosti pouka izvajanega po načelih formativnega spremljanja. Ugotovitve naše študije ne odstopajo od drugih študij, ki proučujejo učinke formativnega spremljanja na dosežke učencev pri matematiki (Van Den Berg in sod., 2017; Rakoczy in sod., 2019). Preverili smo dve hipotezi, na katerih nismo našli pomembnih razlik med dosežki učencev na začetku šolskega leta in ob koncu šolskega leta, našli pa smo razlike med učenci eksperimentalne in kontrolne skupine, predvsem na srednješolskem nivoju. Ker so bile te razlike prisotne že ob merjenju na začetku leta, in so se ohranile tudi pri zaključnem merjenju, nas prav dejstvo, da so učenci v eksperimentalni skupini dosledno, na obeh (v kontekstu širše študije pa ugotavljamo, da na vseh) spremenljivkah, dosegli znatno višje rezultate od učencev $\mathrm{v}$ kontrolni skupini navaja $\mathrm{k}$ sklepu, da pouk po načelih formativnega spremljanja predstavlja rahlo prednost pred poukom, ki ne poteka po teh načelih. Učenci v eksperimentalni skupini na srednješolskem nivoju so bili formativnega spremljanja deležni že v prvem letniku, torej leto pred našim začetnim merjenjem. Sklepamo torej, da so učenci eksperimentalne skupine $\mathrm{z}$ učiteljem, ki je poučeval po načelih formativnega spremljanja, imeli drugačno izkušnjo od učencev, ki so jih poučevali "ne-formativci", kar potrjujejo tudi nekateri odgovori učencev v fokusnih intervjujih (ki pa niso predmet tega prispevka). Učitelji - formativci spodbudam in pozitivnim sporočilom, predvsem izražanju stališča "zmoreš" namenjajo posebno pozornost, saj takšna naravnanost predstavlja osrednjo idejo formativnega spremljanja. Verjetno ni naključje, da je ta razlika prisotna med učenci eksperimentalne in kontrolne skupine na nivoju srednje šole, kjer odnosi učitelj-učenec niso tako prepleteni, vzgojna funkcija šole pa ne tako v ospredju. Raziskava odpira številna nova vprašanja, zato $\mathrm{z}$ raziskovanjem tega področja nadaljujemo $\mathrm{v}$ bolj nadzorovanih okoliščinah ter na večjem številu učiteljev.

\section{Viri in literatura}

Bennett, Randy Elliot. "Formative assessment: a critical review". Assessment in Education: Principles, Policy \& Practice 18, št. 1 (February 2011): 5-25. https://doi.org/10.1080/0969594X.2010.513678.

Black, Paul, and Dylan Wiliam. "Assessment and Classroom Learning". Assessment in Education: Principles, Policy \& Practice 5, št. 1 (March 1998): 7-74. https://doi.org/10.1080/0969595980050102. 
Black, Paul, and Dylan Wiliam. “'In Praise of Educational Research': Formative Assessment.“ British Educational Research Journal 29, št. 5 (October 2003): 623-37. https://doi.org/10.1080/0141192032000133721.

Black, Paul, and Dylan Wiliam. "Developing the theory of formative assessment." Educational Assessment Evaluation and Accountability, št. 21(1) (February 2009): 5-31.

Cankar, Gašper, in Boštjan Bajec. "Velikost učinka kot dopolnilo testiranju statistične pomembnosti razlik." Psihološka obzorja, (Maj 2003): 97-112.

Dunn, Karee, and Sean Mulvenon. “A Critical Review of Research on Formative Assessments: The Limited Scientific Evidence of the Impact of Formative Assessments in Education." Practical Assessment, Research, and Evaluation 14, št. 1 (November 2019). https://doi.org/10.7275/jg4h-rb87.

Dweck, Carol S. " Self-Theories: Their Role in Motivation, Personality, and Development." Philadelphia, Pa.: Psychology Press, 2000.

Holcar Brunauer, Ada, and Cvetka Bizjak, Marjeta Borstner, Janja Cotič Pajntar, Vineta Eržen, Mihaela Kerin, et al. "Formativno spremljanje v podporo učenju: priročnik za učitelje in strokovne delavce. " Ljubljana: Zavod Republike Slovenije za šolstvo, 2016.

James, Mary, and Paul Black, Patrick Carmichael, Colin Conner, Peter Dudley, Alison Fox, David Frost, et al. "Learning How to Learn: Tools for Schools." London, UK: Routledge, 2006. http://www.routledgeteachers.com/ books/Learning-How-to-Learn-isbn9780415400268.

Keeley, Page. "Formative Assessment Probes: Is It Living?" Science and Children 48, št. 8 (April 2011): 24-26.

Korthagen, Fred A. J., and Jos P. A. M. Kessels. "Linking Theory and Practice: Changing the Pedagogy of Teacher Education." Educational Researcher 28, št. 4 (May 1999): 4-17. https://doi.org/10.3102/0013189X028004004.

Marsh, Herbert W., and Xu Man, Andrew J. Martin. “Self-concept: A Synergy of Theory, Method and Application." In APA Educational Psychology Handbook, edited by Karen R. Harris, Steve S. Graham and Tim Urdan, 1 - 75. Washington, D. C.: American Psychological Association, 2012. https://www.researchgate.net/publication/305888854_Effect_of_Using_ Formative_Assessment_Techniques_on_Students__Grades/citations.

Mehmood, Tahir, and Tariq Hussain. "Impact of Formative Assessment on Academic Achievement of Secondary School Students." International Journal of Business and Social Science, 2012, 101-4.

Peat, Mary, and Sue Franklin, Marcia Devlin, Margaret Charles. "Revisiting the Impact of Formative Assessment Opportunities on Student Le- 
arning.“ Australasian Journal of Educational Technology 21, št. 1 (March 2005): 102-17.

Pla-Campas, Gil, and Joan Arumi-Prat, Anna M. Sene-Mir, Eduard Ramirez. “ Effects of using Formative Assessment Techniques on Students' Grades.“ Social and Behavioral Sciences 228 (July 2016): 190-195.

Rakoczy, Katrin, and Petra Pinger, Jan Hochweber, Eckhard Klieme, Birgit Schütze, Michael Besser. "Formative Assessment in Mathematics: Mediated by Feedback's Perceived Usefulness and Students' Self-Efficacy.“ Learning and Instruction 6o (April 2019): 154-165.

Ryan, Richard, and Edward Deci. "Self-Determination Theory and the Facilitation of Intrinsic Motivation, Social Development, and Well-Being." The American psychologist 55 (February 2000): 68-78. https://doi.org/10.1037/ ooo3-066X.55.1.68.

Shayer, Michael. "Cognitive acceleration through science education II: its effects and scope." International Journal of Science Education 21, št. 8 (September 1999): 883-902. https://doi.org/10.1080/095006999290345.

Suban, Mojca, and Melita Gorše Pihler, Jerneja Bone, Karmen Debenjak, Loreta Hebar, Špela Jenko et al. "Formativno spremljanje pri matematiki. Priročnik za učitelje. " Edited by Mojca Suban and Melita Gorše Pihler. Ljubljana: Zavod RS za šolstvo, 2018.

Trumbull, Elise, and Andrea Lash. "Understanding Formative Assessment: Insights from Learning Theory and Measurement Theory." WestEd, april 2013. https://www.wested.org/resources/understanding-formative-assessment -insights-from-learning-theory-and-measurement-theory/.

Van Den Berg, Marian, and Roel J. Bosker, Cor J. M. Suhre. “Testing the Effectiveness of Classroom Formative Assessment in Dutch Primary Mathematics Education." School Effectiveness and School Improvement 29, no. 3 (December 2017): 339-61. https://doi.org/10.1080/09243453.2017.1406376. 